\title{
Critical race theory: Disruption in teacher education pedagogy
}

Andrea Smith ${ }^{1 *}$

Early Childhood through Secondary Education, University of West Georgia

*Corresponding Author: andreas@westga.edu

Received : 2019-NOV-01

Accepted : 2020-MAY-20

DOI: $10.46303 /$ jcve.03.01.4

How to cite this paper: Smith, A. (2020). Critical race theory: Disruption in teacher education pedagogy. Journal of Culture and Values in Education, 3(1), 52-71. https://doi.org/10.46303/jcve.03.01.4

\begin{abstract}
Teacher education programs are charged with preparing teacher candidates to successfully educate student populations that are more racially and culturally diverse than ever. However, a look at graduation rates among teacher education programs proves that the majority still produce, on average, a teaching force that is $80 \%$ White, although White students make up less than $49 \%$ the total Kindergarten-12th (K-12) grade public school population (U.S. Department of Education, 2016). Absent from the dialogue on diversity in teacher education is a discussion on how race and racism are institutionalized and maintained within such programs (Sleeter, 2017). In this article, the use of Critical Race Theory (CRT) offers tools to examine the role of race and racism in teacher education. I further consider the role CRT can play in the disruption of postsecondary rhetoric about teacher education programs. Focus is placed on my own experiences in a Teaching Internship Seminar course when applying the structures of CRT to encourage conversations on disruptive practices that facilitate social justice in a course within a teacher preparation program. The tenets of interest convergence and permanence of racism are examined in the context of course development as pedagogical practices that disrupt normative patterns in teacher education. I conclude by envisioning how faculty in teacher education programs might address these challenges in such a way that offers suggestions derived from these tenets.
\end{abstract}

Keywords: Critical Race Theory, pedagogy, teacher education, disruptors, race, racism 


\section{Introduction}

In this article, I use a Critical Race Theory (CRT) framework as an analytic tool to examine and challenge the tensions, opportunities, and successes inherent in a Teaching Internship Seminar course for preservice teachers as it relates to race in education. In particular, CRT allowed a space for more significant analysis of the socio-historical impact of race and racism in schools and, more importantly, the students in those schools. In particular, I visit two tenets of CRT, interest convergence, and permanence of racism (Ladson-Billings \& Tate, 1995), in an attempt to disrupt the normative pedagogical patterns of hegemony in teacher education. As Gramsci (1971) argued, hegemony is not a top-down approach. Instead, it is maintained through the compliance of subordinate groups by the dominant ones. A significant means for winning this compliance entails the universalizing of the dominant group's interests as the interests of society as a whole. Thus, because schools are microcosms of the larger society, children (often those who are part of the marginalized groups) are taught values, objectives, and cultural and social underpinnings of the dominant class (Giroux, 1983).

Although teacher preparation programs (TPPs) often highlight their commitment to diversity and social justice through mission and value statements, research suggests the overwhelming majority of programs maintain the existing social order through social and cultural reproduction of hegemonic ideas (Akiba, 2011; Bryan, 2017; Cook, 2015). For example, policies such as access to diversity in the teacher preparation curriculum, licensure and evaluation policies that adversely impact Teachers of Color, and recruitment and retention of Teachers of Color continue to reinforce normative patterns of social and cultural reproduction (Cook, 2015). Additionally, as the student population has grown more diverse in $\mathrm{K}-12$ schools around the country, the teacher population has had an inverse effect on its ability to produce a racially diverse group of teachers (Zeichner, 2014). Of the nearly four million primary and secondary teachers in the United States, $83 \%$ are White, and only $8 \%$ are Black, even as more than $15 \%$ of the nation's school-age children are Black (Florian, 2017). As a solution to addressing this issue, some teacher education programs attempt to prepare preservice teachers for racially and culturally diverse classrooms by requiring students to take a course or attempt to embed these skills across the curriculum. However, such courses and pedagogical practices are not sufficiently potent to disrupt deficit theorizing about Students of Color (Amina, 2011).

Many scholars have addressed racial injustices in the United States in a theoretical fashion (Adams et al., 2007; Derman-Sparks \& Phillips, 1997; Frankenberg, 1997; Helms, 1993; Pack-Brown, 1999; Tatum, 1992, 2001) and have experimented with, and presented models in, practically addressing racism in their respective fields. Concerning the field of education, scholars offer a framework using CRT in education (Ladson-Billings, 1998; LadsonBillings \& Tate, 1995; Solorzano, 1997). Specifically, the use of CRT in education provides a foundation for addressing inequities in the educational system that center on race and racism while examining the social, political, and historical context. As such, the use of CRT pedagogy in my Teaching Internship Seminar course has provided me with a space to utilize disruptive practices for counteracting traditional teacher education patterns that perpetuate racism in education. With this in mind, I have chosen to openly address issues of race and 
racism in education within a teacher education program to help students become more aware of the advantages and biases inherent in their positionality that will impact their future classrooms. Future projections show the White student population shrinking to a smaller and smaller proportion of the whole, and the combined populations of students from other ethnic groups increasing so that together, they make up a steadily growing majority (Bohrnstedt et al., 2015).

In the subsequent sections of this article, I elucidate and discuss how I utilized CRT pedagogy in my Teaching Internship Seminar. Inherent in the discussion, CRT pedagogy focuses on two disruptive practices: permanence of racism and interest convergence. I also explain the various methods I use, in addition to highlighting the challenges and implications of using CRT pedagogy in higher education to disrupt the normative patterns in teacher education.

\section{The Origins of Critical Race Theory}

Critical Race Theory, or CRT, builds on Critical Legal Studies (CLS) and radical feminism. Activists and scholars developed CRT during the 1970s as a response to the failure of CLS to address racial inequalities within the legal system effectively. During this time, legal scholars and activists such as Derrick Bell, Alan Freeman, and Richard Delgado realized that the pronounced advances of the civil rights era of the 1960s had stalled and, in many respects, were dissipating (Delgado \& Stefancic, 2007).

$\mathrm{CRT}$ challenges the dominant discourse on race and racism as it relates to the law by examining how legal doctrine is used to subordinate certain racial and ethnic groups (Bell, 1995; Crenshaw et al., 1995; Matsuda, 1995). According to Matsuda (1995), six unifying themes define CRT (see Figure 1 ):

Figure 1: Critical Race Theory Themes

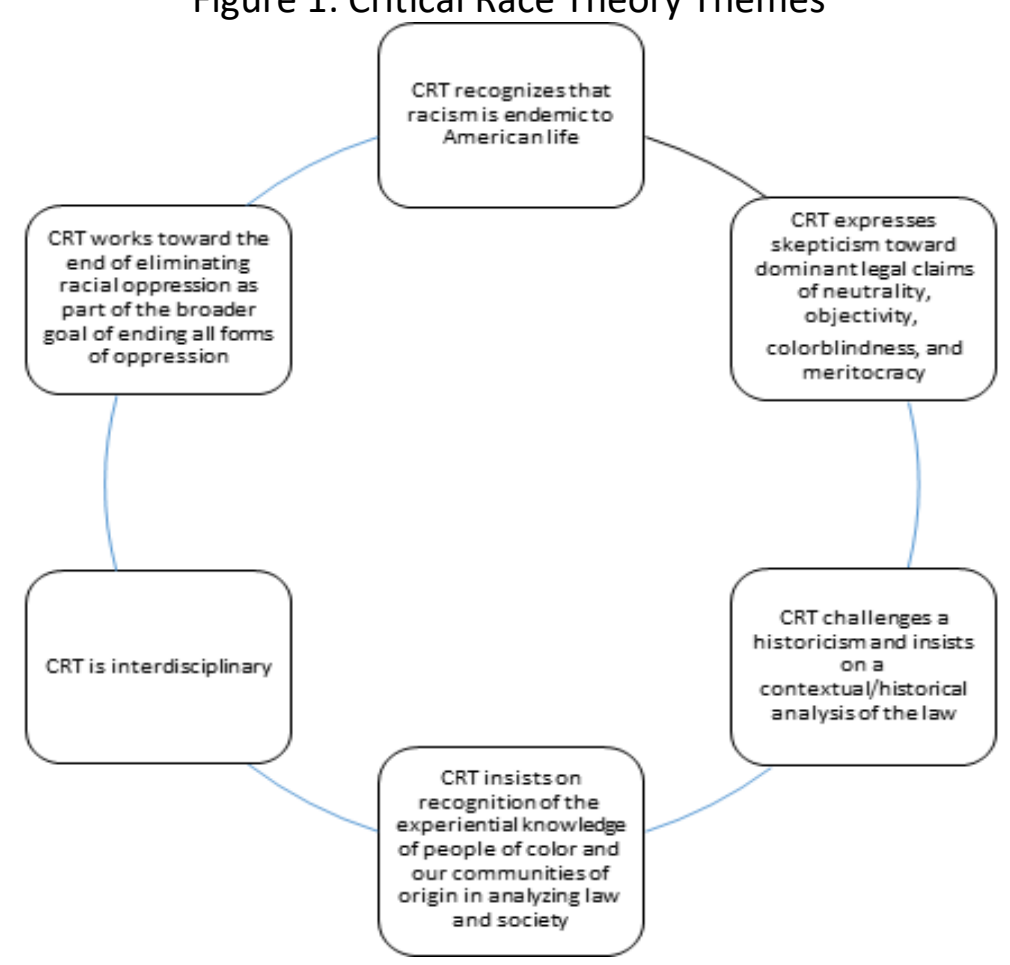

Source: Matsuda, M. J. (2018). Words that wound: Critical race theory, assaultive speech, and the first amendment. Routledge. 
Although CRT was intended as an analytical tool for understanding the law (particularly civil rights law), it is theorized in education as a tool for understanding sustained inequity that Students of Color experience (Ladson-Billings, 1998). In particular, I highlight two themes of $\mathrm{CRT}$, interest convergence, and permanence of racism, to frame my rationale for implementing disruptive practices in my course.

\section{The Permanence of Racism}

A core assertion of CRT is that race is institutional and systemic, and society has maintained power and structures through racism (Solórzano \& Bernal, 2001). The notion of the permanence of racism denotes that racist structures are embedded within all aspects of society. Such structures further privilege White cultural values and norms while Othering People of Color in all spaces, including education (DeCuir \& Dixson, 2004). Since issues of race and racism are deeply embedded in U.S. society and the world as a whole, they are embedded in policies and practices within every sector of society (Milner, 2008).

Consequently, more in-depth analyses of race and racism are needed to address vast inequities that continue to permeate education.

\section{Interest Convergence}

Bell (1987) argued that White people advance the interests of People of Color only when they converge with and advance White interests, a term he coined as "interest convergence." Similarly, Milner et al. (2013) posit interest convergence as "pivotal in underscoring the past and present inequities in education and the larger maintenance of privilege" (p. 343). This perceived loss in Milner et al.'s (2013) view creates fear among White people that systemic changes will threaten power structures that reinforce privileges or result in gains for People of Color that equate to losses for them. For example, when the interests of People of Color are opposed to or at "odds with those in power," it becomes challenging to expose racism and achieve racial equality (Leigh, 2003). Moreover, socially and racially progressive initiatives are systematically scaled back in sectors such as law and education when those initiatives don't serve the dominant population.

\section{Critical Race Theory in Education}

Ladson-Billings and Tate (1995) ushered CRT into education, challenging scholars and educators to raise questions, engage in conscientious dialogue, and produce research in which CRT would serve as a tool and framework to disrupt racelessness in education. Accordingly, CRT in education demonstrates how race and racism manifest themselves in the $\mathrm{K}-12$ pipeline and within pedagogy, curriculum, funding, teacher expectations. For example, CRT "refutes dominant ideology and White privilege while validating and focusing on the experiences of people of color in education" (Yosso, 2005, p. 69). Since race has and continues to be an important issue in American society, racial inequality can be examined in the areas of access, opportunity, and outcomes in K-12 education as it relates to the permanence of racism according to CRT. 
Issues of diversity in education are sometimes addressed, particularly in the last halfcentury, through multicultural education (Banks, 2006). However, similar to Sleeter (2017), I feel this approach tends to broach the issues of racial and ethnic differences by focusing on the diversity children bring with them to the classroom resulting in a method that further fails to name and address the significant implications of race and racism in education settings. This need to limit talk about race and its implications also highlights the interest convergence that is often commonplace in the policies and practices in American society that continue to situate White interests as a priority when considering how racial justice should be met (Bell, 1980).

\section{Critical Race Theory in Teacher Education}

Discussions of race and racism are not highly emphasized in teacher education nor the preparation of teacher educators (Quaye, 2014). Over the past decade, many teacher education programs have attempted to include some form of diversity-related content in their courses (Warren, 2018). However, that coursework often takes the form of one or two separate classes, with the rest of the program giving minimal attention to race, ethnicity, and culture (King \& Butler, 2015). The failure to incorporate race issues in coursework is often due to fear from faculty that students will become angry and upset, fear among some faculty that they are limited in their knowledge of these issues, and feelings that race and racism are not relative (Marx, 2010). Additionally, the previously described general pattern of separating diversity work from the rest of the program characterizes teacher education and its role in reinforcing the status quo that maintains deficit theorizing about Students of Color (Cochran-Smith et al., 2014). To this end, a CRT approach to education entails a commitment on the part of institutions to recognize the various strengths that students and Communities of Color have to offer so that educators move toward social and racial justice.

Although race has been undertheorized in education in general, Milner, Pearman, and McGee (2013) note that "race is grossly under-theorized in teacher education" (p. 339). As such, it provides a helpful lens for analyzing racelessness, definitions of racelessness, in the field of teacher education, and conceptualizing how racelessness might be addressed within teacher education programs. This means that the continued graduation of teachers who lack cultural competence, and who are primarily unprepared to teach racially and ethnically diverse students, is not an aberration. Instead, it is a product of a system that is endemic of racism designed to meet the needs of a White population (Rogers-Ard et al., 2013). Two tenets of CRT are particularly helpful for addressing such issues in teacher education: permanence of racism and interest convergence.

The use of CRT pedagogy in teacher education is essential for preparing the next generation of teachers for diverse schools. While it is not uncommon for courses to have themes of multicultural education, diversity, and cultural competence embedded, I have found that it is still difficult to engage students in discussions about race. My experiences with preservice teachers feel strongly about teaching for equity, but they explicitly ignore the significance race and racism play concerning their teaching. The research on how to teach about race and racism using CRT points to the possibilities and challenges. In particular, Lac (2017) highlights the experience of implementing CRT in a course by using a 
range of critical texts that facilitate analysis of racism and student dialogue to co-construct knowledge. Implications from this study posit the need for more models that support CRT practices for teachers to use and the need for teachers to ground antiracist work within a more extensive structural analysis of race and racism (Parker \& Stovall, 2004). Therefore, as a teacher educator in a faculty position, I am charged with being a catalyst for change and progression in my program to ensure that students become influential teachers of racially and ethnically diverse students.

In 2019, I chose to implement CRT practice in my Teaching Internship Seminar during a Fall semester course. This course was designed as a seminar course for students who are in the final semester of the teacher preparation program and is completed simultaneously with a student teaching internship in preschool or elementary settings. The course is designed to engage interns in a critical examination of issues, topics, materials, and skills appropriate to their professional development and teaching experience during their internship. It also serves as a capstone experience for satisfying the exit requirements of the program. The demographics were similar to national data (Florian, 2017), encompassing 29 students (three Black students-two females and one male, and 26 White female students). So, this course provides an extensive opportunity to engage preservice teachers in CRT pedagogy that disrupt normative patterns in teacher education, which reinforce and maintain racism and deficit thinking in education. I chose, in this course, to use this opportunity to engage students in the CRT tenets of interest convergence and permanence of racism as a way to address hegemonic ideas and values in teacher education. The two tenets further help preservice teachers examine critical issues such as racism, especially as it relates to their role as teachers in diverse classrooms.

Courses related to racial justice may have a variety of learning goals, such as increasing empathy, challenging misconceptions, expanding theoretical perspectives, cultivating analytic skills, or developing tools for productive dialogue (Harbin et al., 2019). Wiggins and McTighe's (2005) note understandings are the "constructivist result of attempts by the student to make sense of the work and lessons, using inquiry, performance, and reflection" (p. 58). For example, the understanding that race is a social construction was vital for students to understand when discussing race. Although there are vast variations in human ethnicity and culture, there is no biological basis for racial categories (Spencer, 2014). This understanding was essential since education policy and practices that are perpetuated by teachers have underpinnings from the Eugenics movement, which highlights theories about fixed intelligence, personality traits, and the educability of marginalized groups (Winfield, 2007). Additionally, the understanding that racism is a system of advantage based on race that is perpetuated through institutions, policies, practices, ideologies, and interpersonal interactions was equally important (Tatum, 1992). These understandings guided my course redesign and helped to serve as a framework for developing instructional activities and assessments aligned with CRT as they relate to examining the permanence of race and racism and interest convergence in education. 


\section{Course (Re) Design with CRT}

Historically, teacher education programs have been a space dominated by White, English-monolingual, middle-class perspectives in the United States (Bryan, 2017). As the student population has grown more diverse in K-12 schools around the country, the teacher population has failed to diversify in a manner that reflects the diverse student population (Zeichner, 2014). In addition to the limited diversity among preservice teachers in teacher preparation programs, the curricular content of teacher education programs tends to reflect White, middle-class culture. Likewise, "the curriculum of teacher education mirrors, in many ways, the K-12 curriculum in that it is Eurocentric and White dominated" (Milner et al., 2013, p. 346 as cited in Sleeter, 2017). Milner (2008) stresses interest convergence is based on the premise that racial equity and equality for People of Color will only be advanced when they converge with the interests, needs, and values of White people. As such, when considering interest convergence, my initial assumption about the lack of integration of topics about race and equity centered on evidence that White teacher educators tend to focus on the emotional needs of White students rather than those of Students of Color (Matias, 2016; Warren \& Hotchkins, 2015).

Lichty and Palamaro-Munsell (2017) noted that many colleges are reexamining their curriculum to expand the representation of marginalized groups and perspectives. For example, I analyzed a past syllabus for my assigned course before I taught it. I found more than half of it stressed celebration of difference rather than systemic inequalities; only $8 \%$ of the syllabi topics explored issues of bias, racism, and systemic power relationships that impact teachers in the classroom through topics such as Response to Intervention (RTI) and interview strategies. To my dismay, the topics only skimmed the surface of diversity and failed to account for how race and racism impact pedagogy. This, in my view, further failed to center race and racism as the cause and context for unequal and inequitable education outcomes (Cook, 2015).

Diversity is often separated in the curriculum, resulting in interests of People of Color not being privileged (Cochran-Smith et al., 2014). As such, institutions serve as a mechanism for maintaining separation of interests while maintaining the status quo, which is problematic to deficit theorizing about People of Color. To this end, I chose to examine and select content for the course - a constellation of texts, media, images in PowerPoint presentations, and learning activities. For example, I selected the required readings in which at least $50 \%$ were authored by Scholars of Color or other marginalized groups. Additionally, although many courses in the teacher preparation program at my university relied heavily on academic articles or books, I recognized this as limited in scope to address issues of race in education. Other possibilities included analyzing (auto)biographical narratives and memoirs that could surface feelings, lived experiences, as well as new understandings about their identity and how it impacted their teaching pedagogy (Delano-Oriaran \& Parks, 2015; Winans, 2005).

Tatum (2007) noted that by framing institutionalized racism in terms of the systematic ways the dominant group often implicitly benefits, it represented an accessible way for my students to understand the concept of institutionalized racism and how it impacts the field of education. As part of normalizing discomfort, I asked students to write 
down concerns they had about talking about race/racism in the Facebook group (e.g., appearing racist, or being a target of other's microaggressions), or their feelings about the topic (Estrada \& Matthews, 2016; Rothschild, 2003). Moreover, to prepare my students to engage in difficult conversations, I equipped them with strategies they could use to deconstruct their perspectives and consider new ways of thinking about racism in education.

Discussions about race have become increasingly difficult in university classrooms, and failure to engage students in such issues as racism often yields teachers who reproduce deficit, hegemonic thinking when they encounter Students of Color. Examination of the findings from Marx's (2010) study highlighted the permanence of race in interactions and teaching strategies employed by the participants. In that study, the beliefs of nine White English-only speaking preservice teachers who tutored English language learners of Mexican origin as part of a university field service requirement. In particular, the study highlighted that the good intentions of the participants were frequently undermined by the Whiteness and the racism that influenced their beliefs about and interactions with the children.

In order to address the difficulty of preservice teachers to examine their own identity and how it intersects with beliefs about race and its impact in education, the use of a social media platform, Facebook, was used in the course to encourage students to serve as active participants in virtual discussions about the permanence of racism in education. This activity promoted an open discussion of course materials and free access to course materials that focus on race in education. It further allowed students' views of race, racism, and racial inequality to be expressed, challenged, and expanded in a virtual race-critical classroom and, ultimately, in their field placements and personal classes in K-12 and post-secondary schools. Social media platforms such as Facebook are, in many ways, responsive to current students' familiarity, comfort, and media sharing abilities.

Specific texts and resources were used as a guide for course discussion centered on three major themes for addressing race and its impact on my students: a) implicit bias and microaggressions, b) White privilege and fragility, and c) social justice. These three themes challenge assumptions about race and look at the underlying social, economic, and political factors that disproportionately allocate advantages and privileges to White citizens in the United States. Ultimately, the resources I selected for use in my course helped foster a classroom in which students were provided opportunities to engage in critical dialogue and recognize patterns of racism and interest convergence in education and society (see Table 1). 
Table 1

Resources on Race in Education

\begin{tabular}{ll}
\hline Theme & Resources \\
\hline $\begin{array}{l}\text { Implicit Bias and } \\
\text { Microaggressions }\end{array}$ & $\begin{array}{l}\text { Project Implicit. (2011). Implicit Association Test. } \\
\text { https://implicit.harvard.edu/implicit/takeatest.html }\end{array}$ \\
& $\begin{array}{l}\text { Niemann, Y. (2017, May 14). Microaggressions in the classroom. [video file]. } \\
\text { https://www.youtube.com/watch?v=ZahtlxW2ClQ }\end{array}$
\end{tabular}
https://www.youtube.com/watch?v=ZahtlxW2CIQ

White Privilege and Fragility
DiAngelo, R. (2015, April 9). White fragility: Why it's so hard to talk to White people about racism. http://goodmenproject.com/featured-content/white-fragility-why-its-so-hard-to-talkto-white-people-about-racism-twlm/

Smith, L. (Writer). (2003). The House We Live In. [Television series episode]. In Smith, L. (Producer). RACE: The Power of Illusion. Los Angeles, CA: Public Broadcasting Service.

My course (re)design set the stage for creating a productive learning environment that encouraged meaningful engagement in activities to support student understanding about race and its impact on education. However, I recognized that it alone was insufficient for addressing unexpected challenges that can arise in teaching about race. While teaching race-related content, I was aware of the research that notes that students often express emotions such as anger or indifference as means to discredit the hegemony of Whiteness in society (Evans-Winters \& Hoff, 2011). I further knew that any number of events could spark strong reactions in the classroom, such as an inappropriate remark from a student, a raciallymotivated attack about specific individuals or groups, an act of hate speech on campus. In essence, Sue and colleagues (2009) posit that these moments require instructors to be astute in their facilitation; however, preparation to handle these moments is often neglected in teacher training programs and courses.

\section{Lessons Learned}

My work is grounded in helping students understand how educators' perspectives are impacted by socio-historical factors concerning minority groups and access to education. 
While implementing non-normative work based on race in my courses, I found that my passion and awareness for such a topic was met with many emotions. Foremost, my feelings included knowledge of the importance of using disruptive practice. Next, I was conscious of the possible backlash and risk of lower student evaluations due to such a high-risk topic (Smith \& Hawkins, 2011), a thought that resonates with me since I am a junior faculty member seeking tenure. I was able to situate these feelings within two lessons learned as they relate to White fragility and the burden of representation.

\section{White Fragility}

Race and racism proved to be an unsettling topic among many of the White students in my course when placed in the context of bias and the possibility that one could harbor deficit thinking tied to beliefs about race. I was very mindful of the fragility among many of my students. In particular, numerous White students expressed concern when discussing race. The lesson I learned in this course about White fragility was to proactively seek resources to support me with empathizing with the emotions among some of my students. DiAngelo (2015) defines White fragility as a "state in which even a minimum amount of racial stress becomes intolerable, triggering a range of defensive moves. These moves include the outward display of emotions such as anger, fear, and guilt, and behaviors such as argumentation, silence, and leaving the stress-inducing situation" (p. 57). I proactively sought to find resources that would highlight this fragility and guide student reflection in a meaningful way. They explored the endemic nature of institutionalized racism-a core principle of CRT. Moreover, I was very intentional about the selection of resources for this class. Each resource served as a framework for discussions about the permanence of racism in schools and our education system.

\section{The Burden of Representation}

Students of Color provided perspectives that centered on feelings of value and voicelessness. Since the student demographics at my university are mostly White on my campus and in my classes (University of West Georgia, n.d.), I wanted to be especially thoughtful about the experiences of Students of Color in my courses. Sue (2010) highlights the heightened pressure among Students of Color to feel like they are targeted to be the 'spokespersons' of their racial group, especially when discussing race and racism issues. This form of microaggression, although covert, results in feelings such as anxiety and isolation (McCabe, 2009). Having shared similar experiences during my education at predominantly White institutions (PWIS), I have first-hand shared experiences that contributed to my own emotions as I acknowledge and often feel the burden of representation within my role at the university that students potentially felt.

Many Students of Color in my classroom spoke up often to discuss issues related to race and racism; however, there were times when they remained silent even when I expected them to provide their perspectives on various topics. So, I was very cognizant of how I evaluated participation during discussions as I realized that some of my Students of Color chose not to participate to retain their personal and cultural identity (White, 2011). It was crucial to determine how it would be evaluated in the course. I knew traditional assessment strategies (e.g., exams, quizzes, or research papers) were not appropriate, as the 
course's goals required performance-based assessments. For example, equipping students with tools for constructive dialogue about educational topics was a key learning objective. While many courses in the program typically assess student learning only in terms of cognitive development, for example, through quizzes, exams, or research papers, assessments in my course included self-and peer reflections on student participation in large and small group dialogue in class. Matias \& Mackey (2016) highlight the benefits of utilizing alternative modes of informal assessment to engage students in critical discussion about race. Essentially, my presence as a Black professor helped mitigate the burden of representation effects by signaling to students that they need not represent their race in the classroom and that I serve as a counterexample to negative stereotypes about People of Color.

\section{Implications}

CRT scholars argue the analysis of structural inequality without sufficient attention to the endemic nature of race and racism in this country is naive and incomplete, at best (Parker \& Stovall, 2004; Stovall, 2006). In particular, topics such as race and racism are often under-examined in K-12 and college settings. Consequently, students and faculty harbor limited understanding of the racial history or policies that shape our lives and educational institutions (Kohli et al., 2017). For my course redesign, I addressed the gap that persists between teacher education programs and the continued production of teachers, mostly White, who, by and large, are limited in their scope and understanding to offer racially/ethnically diverse students a culturally responsive education. Using CRT, I discussed pedagogical approaches that catalyzed the disruption of the normative patterns of teacher education in an attempt to alter the deficit lens that many teachers use to inform their pedagogy and understanding of their students, particularly Students of Color. This approach and redesign of my course helped disrupt the often ignored issue of race and racism in society. Despite identifying and defining interest convergence and permanency of racism, I recognize that students and faculty, mainly White, feel "uncomfortable" and often feel forced to be "politically correct" (Shih, 2017) when such issues are explored. However, the silence of race and racism is an issue that permeates all areas of society, and education is not immune to its impact on Students of Color. In the next section, I present three implications for teacher educators that will guide them with essential implications about developing and implementing course redesign using CRT pedagogy as a disruptive practice.

\section{Expect and Welcome Difficulty}

Education in and of itself is a discomforting process. But, when adding a layer that challenges hegemonic beliefs, it becomes one that requires intentionality about the development of a safe environment for students to explore such perspectives. When exploring topics that center on individual, cultural, and national identities, instructors need to anticipate, welcome, and prepare for conflict (Danowitz \& Tuitt, 2011; Ford \& Malaney, 2012; Housee, 2008). Kumashiro (2000) asserts that "Educators should expect their students to enter a crisis," and in doing so, "provide space in the syllabus for students to work through their crisis in a way that changes oppression" (p. 7). For example, I was able to 
normalize difficulty through initial communication in my syllabus. A statement was provided to remind students about the course's goals but, more specifically, how the purposes of the course will challenge previously held beliefs that relate to the permanence of racism and situate race and racism as significant factors that impact educators and society as a whole.

Although I tried to establish a safe space, I quickly recognized that the idea behind a safe space in my classroom had to be modified to ensure that students would not become defensive and expect their beliefs not to go unchallenged. Leonardo and Porter (2010) challenges the myth behind the safe space. They concluded, "for marginalized and oppressed minorities, there is no safe space...mainstream race dialogue in education is arguably already hostile and unsafe for many students of color whose perspectives and experiences are consistently minimized" (Leonardo \& Porter, 2010, p. 149). As such, instructors should aim for what Arao and Clemens (2013) call a brave space in which students are encouraged to consider the perspectives and ideas that may be new, difficult, and discomforting to their preconceived values and beliefs. As such, the brave space further opened up a critical dialogue about how many of my students' behaviors, whether intentional or not, misaligned with pure intentions of teaching for social justice; a reality that often benefited personal and professional interests without consideration of one's privilege (French, 2019).

\section{Meet Students Where They Are}

Consideration must be given to the campus context and individual students. In some settings, it is not uncommon for college students never to have experienced a Black instructor, never to have deeply considered the history of interest convergence or the permanence of racism and never to have examined bias or their own identity, relationships, or broader societal conditions. As a result, a large deficit presents in many students' ability to talk about race and racism (Delano-Oriaran \& Parks, 2015). Sue (2010) noted that even for contexts in which students have experienced some form of diversity, the vast majority of students, often White, carry beliefs and understandings rooted in misinformation, bias, or internalized beliefs in White superiority (Sue, 2010). Additionally, students' anger and frustration with discussions on race issues can be expressed in course evaluations, which can undermine faculty (Evans-Winters \& Hoff, 2011). Thus, meeting students where they are requires consideration of students' knowledge base, constructing course materials to foster meaningful engagement, and facilitating new understandings. This can be done by applying the principle of interest convergence and the permanence of racism as an analytical tool for examining race and racism in teacher preparation courses that serve to disrupt and privilege normative values while marginalizing the experiences of People of Color. This, as my students expressed, was very eye-opening.

One of the most common responses to my course is, "I had no clue this happens." or "No one ever told me." These responses provided a framework for many discussions and course engagement because it helped students see that they were not alone in their limited understanding, thus establishing openness and receptiveness to learning. For example, in response to students' statements which might lend toward microaggressive comments about individuals or groups (Sue, 2010), an instructor might consider some of the following prompts: 
- Tell me more about that...

- It sounds like you have strong views on this - have you had some personal experience that might help us understand where you are coming from?

- I'm glad you brought this up, because this sentiment is something we hear a lot in popular culture, and it's essential to understand and unpack. What are the concerns underlying this statement? (Zembylas, 2012)

Zembylas (2012) further suggests using "strategic empathy" to engage students who may be misinformed or not exposed to alternative viewpoints. This, in turn, helps to integrate their misinformed views into anti-racist and socially just perspectives.

\section{Instructor Credibility}

Upon considering interest convergence in my TPP, I found it essential to bring racism and racism issues to the forefront as such issues are often ignored due to fears about student discomfort and a possible backlash in the form of negative course evaluations. Further, such issues have been politicized, and there lies a presumption that race and racism is just opinion, rather than a scholarly field (Ladson-Billings, 1998). This, in my view, is far from the truth. Such a presumption about race further catalyzes the implicit bias and discrimination that often presents in teachers of Students of Color (Sue, 2010). So, I recognize that instructor credibility is vital when teaching in higher education.

To establish credibility, I found it valuable to describe my background and training that prepared me to discuss the content and issues of race and racism. However, establishing credibility when discussing issues of race and racism can be a challenge. As an African American junior faculty member, it is essential to note the added layer of challenges that must be considered for Faculty of Color, and as a woman. Research shows that Faculty of Color are more likely to be challenged on their credibility and subjected to criticism and even disrespect in the classroom (Schueths et al., 2013). I do not imply that these issues are more challenging or distressing than the experiences that I, or other Faculty of Color, have reported in the teaching of race-related content. But, I recognize the privilege that my White counterparts encompass when entering a classroom and automatic perception of credibility related to preconceived notions of White privilege in academia (Tuitt et al., 2009).

While credibility is essential for an African American junior faculty member who teaches race-related content, it is also crucial for White faculty. Smith et al. (2017) posit that in addition to mastering subject matter, White faculty must engage in an ongoing process of personal exploration about racial identity and privilege. This means examining how the constructs above inform perceptions of self and racial "others". It further means examining how implicit and explicit bias is exhibited in educational environments and classrooms among Students of Color (Sue, 2010). Smith et. al (2017) argue, "The notion that racism is a system of privilege from which White people can never completely step outside, but to which they can stand in opposition, can in and of itself provoke the beginnings of a cognitive shift for some students" (p. 662). Primarily, White professors can use their credibility to play an influential role in bringing issues of race and racism to the forefront through adoption and modeling a transparent and non-defensive tone about these issues that permeate our society. 


\section{Conclusion}

In this article, I discussed ways in which faculty can utilize CRT to disrupt postsecondary normative patterns in teacher education. Specifically, I provided my personal experiences from my Teaching Internship Seminar course. I outlined how I applied critical race pedagogy to encourage a classroom centered on disruptive practices that facilitate social justice in the teacher preparation program at my university. The examples above demonstrate the benefit and significance of examining interest convergence and the permanence of racism in teacher education preparation programs through CRT pedagogy. Additionally, the patterns based on the tenets of CRT, as mentioned above of CRT, highlight the pedagogical practices and challenges that faculty endure when disrupting oppressive systems in K-12 and higher education that disadvantage Students of Color. In essence, teacher preparation programs have a long way to go, and CRT can and should be used as an essential tool for studying and transforming them to promote social justice.

As junior faculty and a teacher educator, I am fully committed to the disruption of normative patterns in teacher education that serve to reproduce inequities and deficit thinking among teacher candidates. Nevertheless, I am hopeful that CRT pedagogy can be a catalyst for informing change. I fully acknowledge that teacher preparation programs cannot serve as the sole apparatus through which racism and discrimination are disrupted. The growth and conceptualization of CRT in higher education and the K-12 education system demonstrate that although educational institutions have often reproduced inequities, they can also exist and serve as spaces in which educators can commit to racial justice. As Weldon (2009; 2010) emphasizes in his work with teachers, unless professional development creates space for teachers to engage with painful personal legacies of the past, no transformative pedagogies have much chance of succeeding. In closing, teacher educators, and faculty as a whole, must collectively re-envision the future of higher education in a manner that does not merely educate students, but also educates and prepares them to disrupt racism and other forms of racism in our society. 


\section{References}

Adams, M., Bell, L. A., \& Griffin, P. (Eds.). (2007). Teaching for diversity and social justice (2nd ed.). Routledge/Taylor \& Francis Group.

Akiba, M. (2011). Identifying program characteristics for preparing pre-service teachers for diversity. Teachers College Record, 113(3), 658-697.

https://www.researchgate.net/publication/286805295 Identifying Program Charac teristics for Preparing Pre-Service Teachers for Diversity

Banks, J. A. (2006). Race, culture, and education: The selected works of James A. Banks. Routledge.

Bell, D. (1980). Brown and the interest-convergence dilemma. Shades of Brown: New perspectives on school desegregation. Teachers College Press.

Bell, D. (1987). And we are not saved: The elusive quest for racial justice. Basic Books.

Bell, D. A. (1995). Who's afraid of critical race theory? University of Illinois Law Review, 893.

Bohrnstedt, G., Kitmitto, S., Ogut, B., Sherman, D., \& Chan, D. (2015). School Composition and the Black-White Achievement Gap. NCES 2015-018. National Center for Education Statistics.

Bryan, N. (2017). White teachers' role in sustaining the school-to-prison pipeline: Recommendations for teacher education. The Urban Review, 49(2), 326345. https://doi.org/10.1007/s11256-017-0403-3

Cochran-Smith, M., Ell, F., Ludlow, L., Grudnoff, L., \& Aitken, G. (2014). The challenge and promise of complexity theory for teacher education research. Teachers College Record, 116(5), 1-38. https://www.tcrecord.org/content.asp?contentid=17415

Cook, D. A. (2015). Shifting the center in teacher education: An introduction to the special issue on critical race theory and teacher education. The Urban Review, 47(2), 233236. https://doi.org/10.1007/s11256-014-0290-9

Crenshaw, K., Gotanda, N., Peller, G., \& Thomas, K. (1995). Critical race theory. The key writings that formed the movement. The New Press.

Danowitz, M. A., \& Tuitt, F. (2011). Enacting inclusivity through engaged pedagogy: A higher education perspective. Equity \& Excellence in Education, 44(1), 40-56. http://dx.doi.org/10.1080/10665684.2011.539474

DeCuir, J. T., \& Dixson, A. D. (2004). "So when it comes out, they aren't that surprised that it is there": Using critical race theory as a tool of analysis of race and racism in education. Educational researcher, 33(5), 26-31. https://doi.org/10.3102/0013189X033005026

Delano-Oriaran, O. O., \& Parks, M. W. (2015). One black, one white: Power, white privilege, \& creating safe spaces. Multicultural Education, 22, 15-19. https://scholar.googleusercontent.com/scholar?q=cache:YFoQJItLRHAJ:scholar.googl e.com $/ \& h$ l=en\&as $s d t=0,11$

Delgado, R. \& Stefancic, J. (Eds) (2007). The Derrick Bell Reader. New York University Press.

Derman-Sparks, L., \& Phillips, C. B. (1997). Teaching/learning anti-racism: A developmental approach. Teachers College Press. DiAngelo, R. (2011). White fragility. International Journal of Critical Pedagogy, 3(3), 54-70. http://libjournal.uncg.edu/ijcp/article/view/249 
DiAngelo, R. (2015, April 9). White fragility: Why it's so hard to talk to White people about racism. The Good Men Project. http://goodmenproject.com/featured-content/whitefragility-why-its-so-hard-to-talk-to-white-people-about-racism-twlm/

Estrada, F., \& Matthews, G. (2016). Perceived culpability in critical multicultural education: Understanding and responding to race informed guilt and shame to further learning outcomes among White American college students. International Journal of Teaching and Learning in Higher Education, 28(3), 314-325. https://eric.ed.gov/?id=EJ1125096

Evans-Winters, V. E., \& Hoff, P. (2011). The aesthetics of White racism in pre-service teacher education: A critical race theory perspective. Race Ethnicity and Education, 14(4), 461-479. https://doi.org/10.1080/13613324.2010.548376

Florian, L. (2017). Teacher education for the changing demographics of schooling: Inclusive education for each and every learner. In L. Florian \& N. Pantic (Eds.), Teacher Education for the Changing Demographics of Schooling (pp. 9-20). Springer.

Ford, K. A., \& Malaney, V. K. (2012). "I now harbor more pride in my race": The educational benefits of inter-and intraracial dialogues on the experiences of students of color and multiracial students. Equity \& Excellence in Education, 45(1), 14-35. https://doi.org/10.1080/10665684.2012.643180

Frankenberg, R. (Ed.). (1997). Displacing Whiteness: Essays in social and cultural criticism. Duke University Press.

French, K. (2019). The paradox of teaching for social justice: Interest convergence in earlycareer educators. Advance online publication. Urban Education. https://doi.org/10.1177\%2F0042085919850259

Gramsci, A. (1971). Selections from the prison notebooks. International Publishers Co.

Giroux, H. A. (1983). Theory and resistance in education: Toward a pedagogy for the opposition (2nd ed.). Praeger.

Harbin, M. B., Thurber, A., \& Bandy, J. (2019). Teaching race, racism, and racial justice: Pedagogical principles and classroom strategies for course instructors. Race and Pedagogy Journal: Teaching and Learning for Justice, 4(1), 1. https://soundideas.pugetsound.edu/rpi/vol4/iss1/1

Helms, J. E. (1993). I also said, "White racial identity influences White researchers". The Counseling Psychologist, 21(2), 240-243. https://doi.org/10.1177\%2F0011000093212007

Housee, S. (2008). Should ethnicity matter when teaching about 'race' and racism in the classroom? Race, Ethnicity, and Education, 11(4), 415-428. https://doi.org/10.1080/13613320802478960

King, E., \& Butler, B. R. (2015). Who cares about diversity? A preliminary investigation of diversity exposure in teacher preparation programs. Multicultural Perspectives, 17(1), 46-52. https://doi.org/10.1080/13613320802478960

Kohli, R., Pizarro, M., \& Nevárez, A. (2017). The "new racism" of K-12 schools: Centering critical research on racism. Review of Research in Education, 41(1), 182202. https://doi.org/10.3102/0091732X16686949

Kumashiro, K. K. (2000). Toward a theory of anti-oppressive education. Review of Educational Research, 70(1), 25-53. https://doi.org/10.3102\%2F00346543070001025 
Lac, V. T. (2017). In real time: From theory to practice in a critical race pedagogy classroom. Inquiry in Education, 9(1), Article 3. https://digitalcommons.nl.edu/ie/vol9/iss1/3

Ladson-Billings, G., \& Tate, W. F. (1995). Toward a critical race theory of education. Teacher College Record, 97(1), 47-68. https://eric.ed.gov/?id=EJ519126

Ladson-Billings, G. (1998). Just what is critical race theory and what's it doing in a nice field like education? International Journal of Qualitative Studies in Education, 11(1), 7-24. https://doi.org/10.1080/095183998236863

Leigh, P. R. (2003). Interest convergence and desegregation in the Ohio Valley. Journal of Negro Education, 269-296. https://doi.org/10.2307/3211248

Leonardo, Z., \& Porter, R. K. (2010). Pedagogy of fear: Toward a Fanonian theory of 'safety' in race dialogue. Race Ethnicity and Education, 13(2), 139-157. https://doi.org/10.1080/13613324.2010.482898

Lichty, L. F., \& Palamaro-Munsell, E. (2017). Pursuing an ethical, socially just classroom: Searching for community psychology pedagogy. American Journal of Community Psychology, 60(3-4), 316-326. https://doi.org/10.1002/ajcp.12199

Luvvie A. (2018, January 2). Get comfortable with being uncomfortable. [video file]. Retrieved from https://www.youtube.com/watch?v=QijH4UAqGD8

Marx, S. (2010). Regarding Whiteness: Exploring and intervening in the effects of White racism in teacher education. Equity and Excellence in Education, 37(1), 31-43. https://doi.org/10.1080/10665680490422089

Matias, C. E. (2016). Feeling White: Whiteness, emotionality, and education. Sense Publishers.

Matias, C. E., \& Mackey, J. (2016). Breakin' down Whiteness in antiracist teaching: Introducing critical Whiteness pedagogy. The Urban Review, 48(1), 32-50. https://doi.org/10.1007/s11256-015-0344-7

Matsuda, M. (1995). Looking to the bottom: Critical legal studies and reparations. In K. Crenshaw, N. Gotanda, G. Peller, \& K. Thomas (Eds.), Critical race theory: The key writings that formed the movement (pp. 63-79). The New Press.

Matsuda, M. J. (2018). Words that wound: Critical race theory, assaultive speech, and the first amendment. Routledge.

McCabe, J. (2009). Racial and gender microaggressions on a predominantly-White campus: Experiences of Black, Latina/o and White undergraduates. Race, Gender \& Class, 16(1/2),133-151. https://www.jstor.org/stable/41658864

Milner IV, H. R. (2008). Critical race theory and interest convergence as analytic tools in teacher education policies and practices. Journal of Teacher Education, 59(4), 332346. https://doi.org/10.1177\%2F0022487108321884

Milner IV, H. R., Pearman, F. A., III, \& McGee, E. O. (2013). Critical race theory, interest convergence, and teacher education. In M. Lynn \& A. D. Dixson (Eds.), Handbook of critical race theory in education (pp. 339-354). Routledge.

Niemann, Y. (2017, May 14). Microaggressions in the classroom. [Video]. YouTube. https://www.youtube.com/watch?v=Zahtlxw2ClQ

Pack-Brown, S. P. (1999). Racism and White counselor training: Influence of White racial identity theory and research. Journal of Counseling \& Development, 77(1), 8792. https://doi.org/10.1002/j.1556-6676.1999.tb02425.x 
Parker, L., \& Stovall, D. O. (2004). Actions following words: Critical race theory connects to critical pedagogy. Educational Philosophy and Theory, 36(2), 167-182. https://doi.org/10.1111/j.1469-5812.2004.00059.x

Project Implicit. (2011). Implicit Association Test. https://implicit.harvard.edu/implicit/takeatest.html

Quaye, S. J. (2014). Facilitating dialogues about racial realities. Teachers College Record, 116(8), 1-42. https://www.tcrecord.org/Content.asp?Contentld=17500

Rogers-Ard, R., Knaus, C. B., Epstein, K. K., \& Mayfield, K. (2013). Racial diversity sounds nice; Systems transformation? Not so much: Developing urban teachers of color. Urban Education, 48(3), 451-479. https://doi.org/10.1177\%2F0042085912454441

Rothschild, T. (2003). "Talking race" in the college classroom: The role of social structures and social factors in race pedagogy. Journal of Multicultural Counseling and Development, 31(1), 31-38. https://doi.org/10.1002/j.2161-1912.2003.tb00528.x

Schueths, A. M., Gladney, T., Crawford, D. M., Bass, K. L., \& Moore, H. A. (2013). Passionate pedagogy and emotional labor: Students' responses to learning diversity from diverse instructors. International Journal of Qualitative Studies in Education, 26(10), 1259-1276. https://doi.org/10.1080/09518398.2012.731532

Shih, D. (2017, April 7 ). A Theory To Better Understand Diversity, And Who Really Benefits. National Public Radio. https://www.npr.org/sections/codeswitch/2017/04/19/523563345/a-theory-tobetter-understand-diversity-and-who-really-benefits

Sleeter, C. E. (2017). Critical race theory and the Whiteness of teacher education. Urban Education, 52(2), 155-169. https://doi.org/10.1177\%2F0042085916668957

Smith, B. P., \& Hawkins, B. (2011). Examining student evaluations of Black college faculty: Does race matter? The Journal of Negro Education, 80(2), 149162. https://www.jstor.org/stable/41341117

Smith, L. (Writer). (2003). The House We Live In. [Television series episode]. In Smith, L. (Producer). RACE: The Power of Illusion. Los Angeles, CA: Public Broadcasting Service.

Solorzano, D. G. (1997). Images and words that wound: Critical race theory, racial stereotyping, and teacher education. Teacher Education Quarterly, 24(3), 5-19. https://www.jstor.org/stable/23478088

Solorzano, D. G., \& Bernal, D. D. (2001). Examining transformational resistance through a critical race and LatCrit theory framework: Chicana and Chicano students in an urban context. Urban Education, 36(3), 308-342. https://doi.org/10.1177\%2F0042085901363002

Spencer, Q. (2014). A radical solution to the race problem. Philosophy of Science, 81(5), 1025-1038. https://doi.org/10.1086/677694

Stovall, D. (2006). Forging community in race and class: Critical race theory and the quest for social justice in education. Race, Ethnicity, and Education, 9(3), 243-259. https://doi.org/10.1080/13613320600807550 
Sue, D. W. (2010). Microaggressions, marginality, and oppression: An introduction. In D. W. Sue (Ed.), Microaggressions and marginality: Manifestation, dynamics, and impact (pp. 3-22). John Wiley \& Sons Inc.

Sue, D. W. (2016). Race talk and the conspiracy of silence: Understanding and facilitating difficult dialogues on race. John Wiley \& Sons.

Sue, D. W., Lin, A. I., Torino, G. C., Capodilupo, C. M., \& Rivera, D. P. (2009). Racial microaggressions and difficult dialogues on race in the classroom. Cultural Diversity and Ethnic Minority Psychology, 15(2), 183. https://psycnet.apa.org/doi/10.1037/a0014191

Tatum, B. D. (1992). Talking about race, learning about racism: The application of racial identity development theory in the classroom. Harvard Educational Review, 62(1), 125. https://doi.org/10.17763/haer.62.1.146k5v980r703023

Tatum, B. D. (2001). Professional development: An important partner in antiracist teacher education. In S. H. King \& L. A. Castenll (Eds.). Racism and racial inequality: Implications for teacher education (pp. 51-58.) AACTE Publications.

Tatum, B. D. (2007). Can we talk about race?: And other conversations in an era of school resegregation. Beacon Press.

Tuitt, F., Hanna, M., Martinez, L. M., Salazar, M., \& Griffin, R. (2009). Teaching in the line of fire: Faculty of color in the academy. Thought \& Action, 25, 65-74. https://eric.ed.gov/?id=EJ930465

U.S. Department of Education (2015). Enrollment in teacher preparation programs. https://title2.ed.gov/

University of West Georgia (n.d.). Composition of student body. https://www.westga.edu/administration/vpaa/iea/composition-of-student-body.php

Warren, C. A. (2018). Empathy, teacher dispositions, and preparation for culturally responsive pedagogy. Journal of Teacher Education, 69(2), 169-183. https://doi.org/10.1177\%2F0022487117712487

Warren, C. A., \& Hotchkins, B. K. (2015). Teacher education and the enduring significance of "false empathy." The Urban Review, 47, 266-292. https://doi.org/10.1007/s11256$\underline{014-0292-7}$

Weldon, G. (2009). Memory, identity and the politics of curriculum construction in transition societies: Rwanda and South Africa. Perspectives in Education, 27, 177189. https://hdl.handle.net/10520/EJC87519

Weldon, G. (2010). Post-conflict teacher development: Facing the past in South Africa. Journal of Moral Education, 39(3), 353-364. https://doi.org/10.1080/03057240.2010.497615

White, J. W. (2011). Resistance to classroom participation: Minority students, academic discourse, cultural conflicts, and issues of representation in whole class discussions. Journal of Language, Identity \& Education, 10(4), 250-265. https://doi.org/10.1080/15348458.2011.598128

Wiggins, G., \& McTighe, J. (2005). Understanding by design (2nd ed.). Association for Supervision and Curriculum Development. 
Winans, A. E. (2005). Local pedagogies and race: Interrogating White safety in the rural college classroom. College English, 67(3), 253-274. https://www.jstor.org/stable/30044636

Winfield, A. G. (2007). Eugenics and education in America: Institutionalized racism and the implications of history, ideology, and memory. Peter Lang.

Zembylas, M. (2012). Pedagogies of strategic empathy: Navigating through the emotional complexities of anti-racism in higher education. Teaching in Higher Education, 17(2), 113-125. https://doi.org/10.1080/13562517.2011.611869

Zeichner, K. (2014). The struggle for the soul of teaching and teacher education in the USA. Journal of Education for Teaching, 40(5), 551-568.

https://doi.org/10.1080/02607476.2014.956544 